response to a glucose load is greater than normal. ${ }^{6}$ The persistence of hyperglycaemia as a result of impaired insulin sensitivity is a continuing stimulus to secretion by the $\beta$ cells. In contrast, in some young diabetics and in severe longstanding adult cases the insulin activity in the serum is very low, ${ }^{8}$ and this could represent a later phase of islet cell exhaustion.

Is anything known of the nature of the possible antagonists ? J. Vallance-Owen has found a substance in the serum of insulin-dependent diabetics which inhibits the stimulating effect on glucose uptake of adding insulin to the isolated rat diaphragm. It is also found after separation of the serum albumin fraction in obese and latent diabetics. Because it is not albumin itself he calls it the synalbumin antagonist, ${ }^{\circ}$ and for various reasons has latterly proposed the interesting idea that it is the B chain of the insulin molecule itself. ${ }^{10}$ The formation of the antagonist is dependent on pituitary and adrenal function. ${ }^{11}$ Non-diabetic relatives may show antagonism in a way that suggests the factor is inherited as a Mendelian dominant. ${ }^{12}$ A large proportion of non-diabetic patients who have had a myocardial infarct also show synalbumin antagonism. Both results imply that many more of the population are constituted as diabetics than show diminished glucose tolerance. Though Vallance-Owen's work may need confirmation' it supplies a satisfying hypothesis to explain some of the facts about the cause and the epidemiology of the disease.

It has long been known that anterior pituitary and adrenal hormones are antagonistic to insulin. Thus thirty years ago Houssay showed that a pituitary hormone identified subsequently as growth hormone by F. G. Young exerted a diabetogenic effect in the intact animal. P. J. Randle has put forward the important concept that this is because of an interrelationship between glucose and fat metabolism which he calls the glucose/fatty acid cycle. ${ }^{13} 14$ In this scheme the uptake of fatty acids for oxidation by muscles inhibits their assimilation of glucose, and the insulin antagonistic activity of growth hormone is a consequence of its lipolytic action in raising the plasma level of non-esterified fatty acids. Adrenaline and cortisol act synergistically with growth hormone to produce a similar effect. Placental lactogen also acts like growth hormone ${ }^{15}$ and may thus account for the rise in insulin requirement usually found in diabetic women during pregnancy. Studies in man have confirmed that increase in non-esterified fatty acids in the plasma results in impaired carbohydrate tolerance and antagonizes endogenous insulin. ${ }^{1}$ While it is not proposed that over-secretion of growth hormone or cortisol is a common cause of diabetes, other unknown factors stimulating the release of fatty acids from adipose tissue might antagonize insulin and in time lead

\footnotetext{
- Kipnis, D. M., and Stein, M. F., in Ciba Colloquia on Endocrinology, ed. M P. Cameron and M. O'Conner, 1964, 15, 156.

- L yngsae, J., Acta med. scand., 1965, 179, Suppl No 441

Welborn, T. A., Richards, R., and Russell Fraser, T., Brit. med. 3., 1967 , 1, 719 .

'McCullagh, E. P., Cook, J. R., and Shirey, B. K., Diabetes, 1958, 7, 298.

- Oakley, W. G., Jones, V. E., and Cunliffe, A. C., Brit. med. F., 1967, $2,134$.

- Berson, S. A., and Yalow, R. S., Drabetes, 1965, 14, 549

'Rudnick, P. A., and Taylor, K. W., Brtt. med. Y., 1965, 1, 1225.

Berson, S. A., and Yalow, R. S., in Ciba Colloquia on Endocrinology, ed. G. E. W. Wolstenholme and M O'Connor, 1962, 14, 182.

- Vallance-Owen, ,o, in Ciba Colloqura on Endocrinology, 1964, 15, 217.

11- Pfizer Medical Monographs, $196 \mathrm{kh}$, No. 1, 22.

$"$ - and Lilley, M. D.. Lancet, 1961, 1.804.

12 and Ashton, w. L. Diabetes, 1963, 12, 356.

1s Randle, P. J., Garland, P. B., Hales. C. N., and Newsholme, E. A., in Ciba Colloyuia on Endocrinology, 1964, 15, 192.

16 Diaberolngra, 1966, 2, 237

Kalkof, R., Schalch, D. S., Walker, J. L., Beck, P., Kipnis, D. M.,
and Daughaday, W. H., Trans. Ass. Amer. Phycns, 1964, 77, 270.
}

to glucose intolerance. This hypothesis neither excludes the additional importance of serum antagonists nor takes into account the possible importance of the rate of synthesis, release, and breakdown of insulin itself.

\section{Artificial Hearts}

Successful homotransplantation of the heart will be considerably more difficult than homotransplantation of an organ which is composed of repetitive units, such as the kidney or the liver. Some of the problems encountered during the early work on implantable artificial hearts were reviewed in these columns two years ago, ${ }^{1}$ and since then studies in large animals such as the calf ${ }^{2}{ }^{3}$ have shown that such a venture is now possible.

One of the major difficulties in developing an artificial heart is that it cannot be used intermittently like a haemodialysis unit. H. B. Shumacker and his colleagues have recently described their work towards developing a totally implantable, reliable mechanical heart. ${ }^{4}$ They used an electrohydraulic pumping system with "ventricular" blood contained in two contiguous Silastic bladders, which were emptied alternately by the movement of fluid within an outer semi-rigid housing. This fluid space was connected by large-bore plastic tubing to a hydraulic pump and electric motor which were placed in the abdomen. It was found that autoregulation of the stroke output of this artificial heart according to the venous return resulted in a satisfactory flexible cardiac output. Normal pressures in both the pulmonary and systemic circulations were maintained, since these depend upon the normal vasoregulation of the peripheral vascular bed rather than on the heart itself. For this reason the pressure pulses produced by the artificial heart were found closely to resemble those produced by the healthy heart.

Thromboses and mechanical haemolysis have continued to be a major complication after the insertion of prosthetic valves into the human heart, ${ }^{5}$ and this problem will also have to be solved for any valves that are to be incorporated in a complete artificial heart. Shumacker and his colleagues have designed one-piece silicone rubber valves which fold closed into a " $C$ " or " $S$ " shape for the inflow and outflow valves, respectively, and which open into a full circle. This design will permit the central flow of blood and should diminish both the turbulence around and the stagnation beyond the caged-ball valve-serious disadvantages which are unavoidable with the use of a central obturator. Thus the first heart model developed by Shumacker and his colleagues has not so far apparently been associated with thrombotic or haemolytic complications. Probably artificial hearts developed in the future will incorporate aortic valve homografts or heterografts. Another, and even better, possibility would be to replace the valves altogether by a roller or finger type of pump, which would maintain unidirectional flow by the compression of Silastic tubes.

is Brit. med. F., 1965, 1, 1510.

Akutsu, T., Mirkovitch. V., Topaz, S. R., and Kolf, W. J., f. thorac cardiovasc. Surg., 1964, 47, 512 .

Gibbon, J. H., jun., Surgery, 1966, 59, 1

Burns, W. H., Shumacker, H. B., and Loubier, R. J., Ann. Surg., 1966, $164,445$.

Starr, A., Edwards, M. L., McCord, C. W., Wood, J., Herr, R., and Griswold, H. E., Circulation, 1964,29 , Suppl. p. 30 .

- Kusserow, B. K., and Clapp, J. F. III, Trans. Amer. Soc. artił. intern. Organs, 1964, 10, 74.

- Loehr. M. L., Kisch, W. F. III, Singer, M., Pierce, W. S., and Kirby, C. K., ibid., 1964, 10, 147. - Schuder, J. C., Stephenson, H. E., and Townsend, J. F., ibid., 1961, 
The provision within the patient's body of a compact power supply for the artificial heart is another major problem that has to be solved. 'It has been found impossible to use power from another muscle, because apparently no other type of muscle can withstand the constant activity that is required. ${ }^{6}$ 7 Implantation of batteries has so far proved impracticable because the large amount of power required means they must be large and frequently replaced. The size of batteries might be reduced by partially recharging them from power generated by muscular contraction. ${ }^{8} \mathrm{~J}$. C. Schuder has recently shown that sufficient electrical energy may be transmitted across the intact chest wall to drive an artificial heart by means of a radio-frequency signal and a portable external power source. $^{8}$

Replacement of the human heart is likely to become possible. Nevertheless, it must be remembered that about a third of the population die from heart disease. The philosophical and moral problems of selecting patients for treatment are thus likely to prove even more difficult than they are for continued renal dialysis.

\section{Absorption of Toxic Drugs from Burns}

Many different forms of local treatment, including the application of soluble compounds, have been recommended for burns, and local prophylaxis by some antimicrobial agents has been found to be highly effective. ${ }^{1-4}$ Though compounds of large molecular size (such as polymyxin) are not easily absorbed, sulphonamides appear readily in the blood stream when applied to extensive burns $^{3 \mathrm{~s}}$; small amounts of silver have been found in the tissues of burned patients treated with silver nitrate compresses $^{4}$; and lactosuria has been reported in patients whose burns were treated with lactose powder. Antibiotics and other agents which are considered too toxic for systemic use are often applied locally without obvious ill-effect, but the safety of this procedure depends on the nature of the compound and on the nature and extent of the lesion requiring treatment.

The risk that soluble compounds applied to burns may cause severe toxic effects is shown in a recent report ${ }^{7}$ by D. S. C. Procter, of Port Elizabeth in South Africa. During a period of 29 months he found that 36 out of 605 children admitted to a burn unit developed coma, which lasted for periods varying from one day to 38 days. The mortality in these patients was higher than expected, and coma occurred in 15 of the 30 who died. Unlike the coma which may develop in burned patients with septicaemia, bronchopneumonia, or electrolyte imbalance, the condition described by Procter appeared in patients who were not suffering from general illness or fever. Initially these patients developed irritability, and this was followed by apathy and by coma.

1 Jackson, D. M., Lowbury, E. J. L., and Topley, E., Lancet, 1951, 2,

Moyer, C. A., Brentano, L., Gravens, D. L., Margraf, H. W., and Monafo, W.' W., Arch. Surg., 1965, 90, 812.

- Moncrief, J. A., Switzer, W. E., Order, S. E., and Mills, W., f. Trauma, 1965, 5, 601.

- Cason, J. S., Jackson, D. M., Lowbury, E. J. L., and Ricketts, C. R., Brit. med. f., 1966, 2, 1288 .

- Cort. med. F., C96, A. M. Gibson, T. and Todd, J. P., in Med. res. Coun. Spec. Rep. Ser. 249, Studies of Burns and Scalds, 1944, p. 16. London.

- Baar, S., and Bull, J. P., Lancet, 1952, 1, 978.

; Baar, S., and Bull, S. Afr. med. F., 1966, 40, 1116

- Procter, D. S. C., S. Atr. medictrial Toxicology, 1957, 2nd ed., p. 245. Baltimore.
During the latter the patients developed a fall in blood pressure and an increase in pulse rate and, later, oliguria, renal failure, and hypothermia.

From the distinctive pattern of symptoms and the consistently negative findings in a range of biochemical and bacteriological tests, it seemed likely that the condition was due to some component of the treatment. Coma occurred only in patients whose burns were dressed-and often appeared shortly after the application of dressings, which consisted of gauze mesh impregnated with $80 \%$ hexylene glycol. When this material came under suspicion, patients who developed coma had their dressings removed, and they recovered from coma after periods which were proportional to the duration of coma. There could be little doubt that the condition was due to absorption of hexylene glycol from the dressings-a conclusion which is supported by the similarity of the toxic signs to those recorded after ingestion of other glycols. ${ }^{8}$

In oral and parenteral therapy toxic effects of drugs are avoided by not exceeding a recommended dosage. Local therapy of burns, however, cannot be standardized by dosage in this way, and hence compounds known to have dangerous toxic effects should not be applied to extensive burns, and all agents considered for local treatment should be investigated for safety as well as clinical value.

\section{Change in New Zealand}

Next month the New Zealand Branch of the B.M.A. will become the Medical Association of New Zealand. This marks the end of a link with the B.M.A. which has existed for nearly 40 years. With the change of title comes autonomy, and a new national medical association will take its place alongside others from the Commonwealth of like history. The advance from local medical society, to B.M.A. Branch, and finally to full independence is a natural and healthy progression. It well reflects the growing strength and stature of the profession in New Zealand. The new Medical Association of New Zealand as it attains its majority can be assured of the warmest wishes and congratulations of its parent and sister associations.

Change must have been in the air at the meeting in Christchurch last February' at which these formative decisions were made. After 28 years in the chair Dr. J. O. Mercer announced his retirement from the editorship of the New Zealand Medical fournal. His has been a notable tenurethe longest since the journal first made its appearance in 1887 - and he leaves his successor, Mr. R. G. Robinson, who is a neurosurgeon (see p. 647), with a firm foundation on which to build. From being a small handbook-sized periodical of principally local interest he has turned the New Zealand Medical fournal into the elegant monthly publication now familiar to doctors all over the world. Dr. Mercer's services to New Zealand medicine have been unstinted and varied. Besides his post as director of pathology to the Wellington Hospital Board he has found time to hold high office in the New Zealand Branch and to serve on the New Zealand Medical Research Council. $\mathrm{He}$ is at the moment chairman of the Medical Council of New Zealand, the equivalent of our G.M.C. But his successful launching of the New Zealand Medical fournal upon the international scene must surely rank as highly as any of his distinguished achievements.

$$
1 \text { N.Z. med. F., 1967, 66, } 188 .
$$

